Article

\title{
Catalytic Cracking of Heavy Crude Oil over Iron-Based Catalyst Obtained from Galvanic Industry Wastes
}

\author{
Estefanía Villamarin-Barriga ${ }^{1}{ }^{\mathbb{D}}$, Jéssica Canacuán ${ }^{1}$, Pablo Londoño-Larrea ${ }^{1}{ }^{\mathbb{D}}$, Hugo Solís ${ }^{1}$, \\ Andrés De La Rosa ${ }^{1}$, Juan F. Saldarriaga ${ }^{2} \mathbb{D}$ and Carolina Montero ${ }^{1, * \mathbb{D}}$ \\ 1 Chemical Engineering Faculty, Universidad Central del Ecuador, Ritter s/n \& Bolivia, Quito 17-01-3972, \\ Ecuador; jevillamarin@uce.edu.ec (E.V.-B.); jessicacanacuan@gmail.com (J.C.); \\ palondono@uce.edu.ec (P.L.-L.); hfsolis@uce.edu.ec (H.S.); adelarosa@uce.edu.ec (A.D.L.R.) \\ 2 Department of Civil and Environmental Engineering, Universidad de los Andes, Carrera 1Este \#19A-40, \\ Bogotá 111711, Colombia; jf.saldarriaga@uniandes.edu.co \\ * Correspondence: cdmontero@uce.edu.ec; Tel.: +593-22544361
}

Received: 2 June 2020; Accepted: 17 June 2020; Published: 3 July 2020

\begin{abstract}
Sewage sludge from the galvanic industry represents a problem to the environment, due to its high metal content that makes it a hazardous waste and must be treated or disposed of properly. This study aimed to evaluate the sludge from three galvanic industries and determine its possible use as catalysts for the synthesis of materials. Catalyst was obtained from a thermal process based on dried between $100-120{ }^{\circ} \mathrm{C}$ and calcination of sludges between 400 to $700{ }^{\circ} \mathrm{C}$. The physical-chemical properties of the catalyst were analyzed by several techniques as physisorption of $\mathrm{N}_{2}$ and chemisorption of $\mathrm{CO}$ of the material. Catalytic activity was analyzed by thermogravimetric analysis of a thermo-catalytic decomposition of crude oil. The best conditions for catalyst synthesis were calcination between 400 and $500{ }^{\circ} \mathrm{C}$, the temperature of reduction between 750 and $850{ }^{\circ} \mathrm{C}$ for $15 \mathrm{~min}$. The catalytic material had mainly Fe as active phase and the specific surface between $17.68-96.15 \mathrm{~m}^{2} \cdot \mathrm{g}^{-1}$, the catalysts promote around $6 \%$ more weight-loss of crude oil in the thermal decomposition compared with assays without the catalyst. The results show that the residual sludge of galvanic industries after thermal treatment can be used as catalytic materials due to the easiness of synthesis procedures required, the low E-factor obtained and the recycling of industrial waste promoted.
\end{abstract}

Keywords: sludge; catalytic material; galvanic industry; waste valorization

\section{Introduction}

The generation of waste worldwide for 2016 was estimated at 2.01 billion tons, while the world generation is expected to reach 3.30 billion $t \cdot$ day $^{-1}$ by 2100 [1]. The global trend shows that industrial waste generation is almost 18 times higher than municipal waste. Industrial waste increases significantly as income level increases [1]. Among these is the waste from the galvanic industry, which produces on average in the United States about 150,000 t.year ${ }^{-1}$ [2], similar values are reported by the European Union [3]. Sludge represents approximately $25 \mathrm{~m}^{3}$ for every million tons of textile wastewater and two-thirds of these sludges have physicochemical properties that can be modified $[4,5]$.

The recovery of galvanic baths is beneficial in the mechanical industry to avoid corrosion problems in materials [6]. Nevertheless, it generates hazardous industrial waste as the residual sludge of the process baths, mainly from rinsing in the stages of stripping and degrease [7].

Since galvanic sludge wastes are hazardous due to their chemical composition, they need final treatment or disposal in a safe landfill. Worldwide the implemented skills are mainly: disposal in 
soils, thermal treatments as pyrolysis/incineration [8-11], encapsulation [12], as a component of other solid materials $[3,7,13-15]$. Similarly, some techniques as inertization of heavy metals present in this type of sludge have been studied [2]. However, these treatments represent additional costs for galvanic companies.

The sludge of the galvanic industry has been mainly treated by thermochemical processes such as pyrolysis and incineration. The byproducts of this process have been used as adsorbents $[5,16]$. Due to the diverse metallic content of this residual industrial sludge, there is the possibility of recovering these residues for the synthesis of catalysts [15,17-20]. Sludge obtained from waste from textile industries, aluminum, galvanic and tannery can be converted on a catalyst for the oxidation of the propane, getting conversions of more than $95 \%$ [21,22].

Catalysts prepared from the sludge of the process of ferrite were tried for $\mathrm{CO}$ conversion, the results indicate that the $\mathrm{Cu}$-ferrite catalyst can convert $\mathrm{CO}$ to $\mathrm{CO}_{2}$ at an inlet $\mathrm{CO}$ concentration of $4000 \mathrm{ppm}$ and a space velocity of $6000 \mathrm{~h}^{-1}$ were held at $140{ }^{\circ} \mathrm{C}$ [23]. The selective catalytic NO reduction was studied using metal catalyst doped with carbon from the residual sludge of ferrite, at $300{ }^{\circ} \mathrm{C}$ conversion $>99.7 \%$ of $\mathrm{NO}$ was reported [24]. The sludge waste from wastewater treatment in the textile industries has metals like $\mathrm{Fe}$ and $\mathrm{Cr}$ were used as catalytic materials during their reducing phase for the decomposition of hydrocarbons [25]. Fe-char catalyst from tank cleaning oily sludge for the catalytic cracking of oily sludge at $800{ }^{\circ} \mathrm{C}$, the oil conversion efficiency reached is around $95.8 \%$ [26]. Carbon-silica derived from SiC-Si sludge has been proven as support for Fe catalysts; better results are shown when Fe was loaded by chemical vapor infiltration than incipient wetness impregnation [27]. Metallic iron from the dyeing sludge ash was probed as a catalyst for biomass gasification. It showed similar behavior that of the commercially available iron-chrome-based catalyst for the same equivalent total amount of $\mathrm{Fe}_{2} \mathrm{O}_{3}$ [28].

This work has aimed to evaluate residual sludge from the galvanic industry as catalysts for which this work raises the synthesis of catalytic materials applied in the reactions of cracking of heavy crude oil.

\section{Results and Discussion}

\subsection{Sludge and Catalyst Characterization}

The thermal treatment (calcination) provided the catalytic characteristics at the residual sludge as the drying of the internal water, volatile substances. The metallic content in the sludge was oxidized in this process. Elemental analysis was done to evaluate the organic material eliminated by calcination.

The results of the elemental analysis and physical properties of the dried sludges and catalytic material obtained are shown in Table 1 . With a prior drying process can be observed that the optimal drying temperature is $120^{\circ} \mathrm{C}$ for $\mathrm{L} 1$ and $\mathrm{L} 2$ and $100^{\circ} \mathrm{C}$ for L3, the differences in the drying temperature can be due at the presence of different compounds and additives on the sludges [29-31].

There was observed that thermal treatment promotes changes in the physical-chemical composition of raw sludge. A higher quantity of sulfur was detected on C3, probably due to the use of sulfuric acid and other sulfur compounds in the galvanic process, with the increase of temperature, these compounds could be converted in oxides [32]. On the C1 and C2 catalyst, the sulfur content was constant. From L2 and its derived catalytic material $\mathrm{C} 2$, the content of carbon is higher than the others. It could be due to carbonates and surfactants used on the stripping process [33]. Carbon and sulfur values are low compared with the reported by other authors in this type of sludge, finding carbon content between $25 \%$ to $40 \%$ and for sulfur between $4 \%$ and $22 \%[5,13,16]$.

Table 1 shows the effects of calcination temperature on the reduction of surface area and pore volume of catalytic materials. The decrease of surface area can be associated with the collapse of the pore structure $[21,34]$. The catalyst with the highest surface area was $\mathrm{C} 1$. For calcination temperature of $400^{\circ} \mathrm{C}$, the three catalysts showed more upper surface area than the other temperatures, but the high organic content can decrease the catalytic activity. Due to the low surface area, the samples calcined 
at $700{ }^{\circ} \mathrm{C}$ have not been used on the catalytic activity test because the physisorption capability can be disfavored.

Table 1. Elemental analysis and physical properties of dried residual sludges (L1-L3) and catalytic material synthesized (C1-C3).

\begin{tabular}{|c|c|c|c|c|c|c|c|c|}
\hline Sample & $\mathrm{T},{ }^{\circ} \mathrm{C}$ & $\% \mathrm{~N}$ & $\% \mathrm{C}$ & $\% \mathrm{H}$ & $\% \mathrm{~S}$ & $\begin{array}{c}\text { Surface Area, } \\
\mathrm{m}^{2} \cdot \mathrm{g}^{-1}\end{array}$ & $\begin{array}{c}\text { Pore Volume, } \\
\mathrm{cm}^{3} \cdot \mathrm{g}^{-1}\end{array}$ & E-Factor \\
\hline L1 & 120 & 0.10 & 2.36 & 2.05 & 0.94 & $\mathrm{~nm}$ & $\mathrm{~nm}$ & $\mathrm{~nm}$ \\
\hline \multirow{3}{*}{$\mathrm{C} 1$} & 400 & 0.02 & 0.65 & 0.35 & 0.39 & 96.15 & 0.12 & \multirow{3}{*}{0.1} \\
\hline & 500 & 0.05 & 0.44 & 0.19 & 0.38 & 71.37 & 0.10 & \\
\hline & 700 & 0.03 & 0.16 & 0.08 & 0.35 & 14.98 & 0.02 & \\
\hline \multirow[t]{2}{*}{ L2 } & 120 & 0.15 & 6.48 & 0.52 & 0.20 & $\mathrm{~nm}$ & $\mathrm{~nm}$ & $\mathrm{~nm}$ \\
\hline & 400 & 0.02 & 5.48 & 0.18 & 0.22 & 73.46 & 0.10 & \multirow{3}{*}{0.1} \\
\hline \multirow[t]{2}{*}{$\mathrm{C} 2$} & 500 & 0.03 & 5.48 & 0.14 & 0.23 & 63.36 & 0.09 & \\
\hline & 700 & 0.01 & 4.77 & 0.08 & 0.20 & 27.56 & 0.03 & \\
\hline \multirow[t]{2}{*}{ L3 } & 100 & 1.11 & 5.86 & 1.35 & 2.94 & $\mathrm{~nm}$ & $\mathrm{~nm}$ & $\mathrm{~nm}$ \\
\hline & 400 & 0.04 & 1.74 & 0.08 & 3.71 & 29.72 & 0.03 & \multirow{3}{*}{0.3} \\
\hline \multirow[t]{2}{*}{$\mathrm{C} 3$} & 500 & 0.03 & 0.40 & 0.08 & 4.23 & 17.68 & 0.02 & \\
\hline & 700 & 0.02 & 0.20 & 0.06 & 4.42 & 4.53 & 0.01 & \\
\hline
\end{tabular}

To determinate the sustainability of this process, the Environmental Factor (E) was calculated [35-37]. E-factor correlates the actual amount of waste produced in the process with the desired product $(\mathrm{E}=$ mass of waste/mass of product). In this case, the desired product was the catalyst. The ideal E-factor is zero. The values E-factor are in Table 1; there were between 0.1 and 0.3 . This process is sustainable because it can valorize industrial waste minimizing the waste produced in the process [35]. The galvanic companies gave the information that raw sludges had metallic content based on iron and zinc. The MSDS and technical data sheets of the streams on the galvanic processes verified it.

Figure 1 shows the FTIR analysis that allows the identification of functional groups for both sludge and catalytic materials. On L1 and $\mathrm{C} 1 \mathrm{OH}$ groups were observed, probably due to $\mathrm{Zn}(\mathrm{OH})$ $\left(1407,1478\right.$ and $\left.1630 \mathrm{~cm}^{-1}\right)$ and other bands in $448 \mathrm{~cm}^{-1}\left(\mathrm{Fe}_{2} \mathrm{O}_{3}\right)$ and $584 \mathrm{~cm}^{-1}\left(\mathrm{Fe}_{3} \mathrm{O}_{4}\right)$ [38]. For L2 and $\mathrm{C} 2$ were identified bands on 2864 and $875 \mathrm{~cm}^{-1}$ correlated with $\mathrm{FeOO}$ bond, on $464 \mathrm{~cm}^{-1}$ for $\mathrm{Fe}_{2} \mathrm{O}_{3}$ and $799 \mathrm{~cm}^{-1}$ for FeO. The presence of $\mathrm{ZnO}\left(606,712\right.$ and $\left.571 \mathrm{~cm}^{-1}\right)$ and $\mathrm{Zn}(\mathrm{OH})\left(1801 \mathrm{~cm}^{-1}\right)$ also were detected [39]. Additionally, the band on $448 \mathrm{~cm}^{-1}$ identified on L3 and C3 can be associated with $\mathrm{FeSO}_{4}$ [40]. In the sludges, it was observed other peaks at 2923 and $3373 \mathrm{~cm}^{-1}$, related to OH bonds due to the presence of the Fe-Zn hydroxyl groups on the surface [41], these bonds decrease its intensity while the calcination temperature increases.
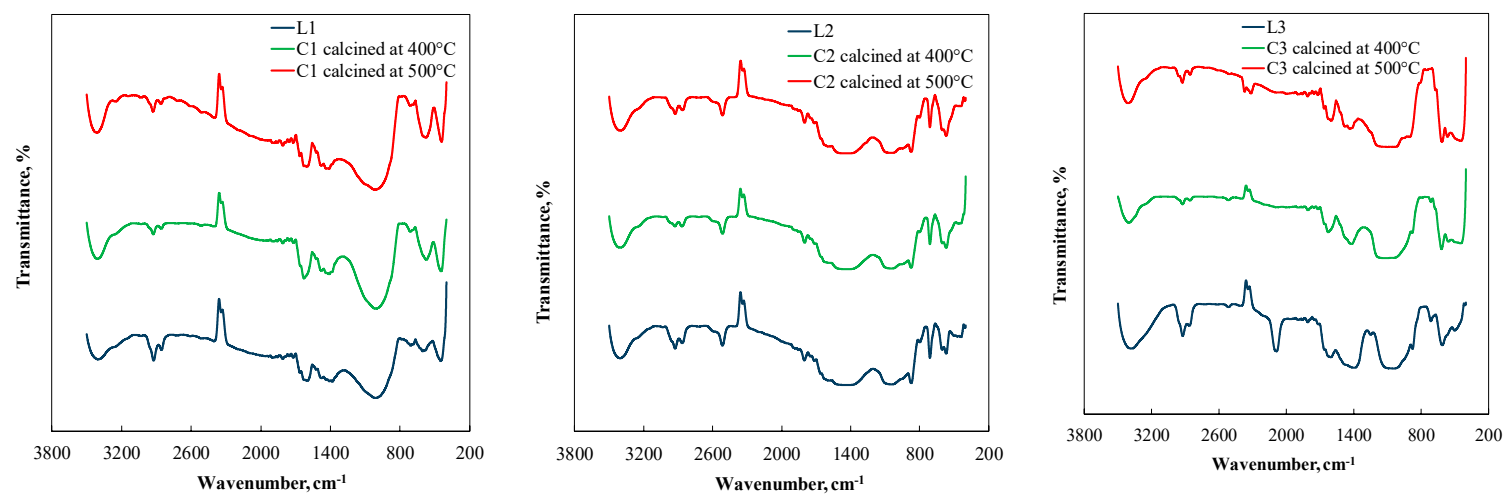

Figure 1. Fourier transform infrared spectroscopy (FTIR) spectra of galvanic sludge and catalytic material. 


\subsection{Catalyst Reducibility Analysis}

The reducibility capability of the synthesized catalysts was studied using the reduction at program temperature (TPR) with hydrogen as a reduction agent, $\mathrm{H}_{2}-\mathrm{TPR}$ profiles are shown in Figure 2. $\mathrm{C} 1$ and $\mathrm{C} 2$ catalysts show three regions for reduction: the first region around $300-550{ }^{\circ} \mathrm{C}$, the second and the prominent area around $550-800{ }^{\circ} \mathrm{C}$, while the third region located between $800-900{ }^{\circ} \mathrm{C}$. In the case of $\mathrm{C} 3$ shows only one prominent peak at $650^{\circ} \mathrm{C}$.
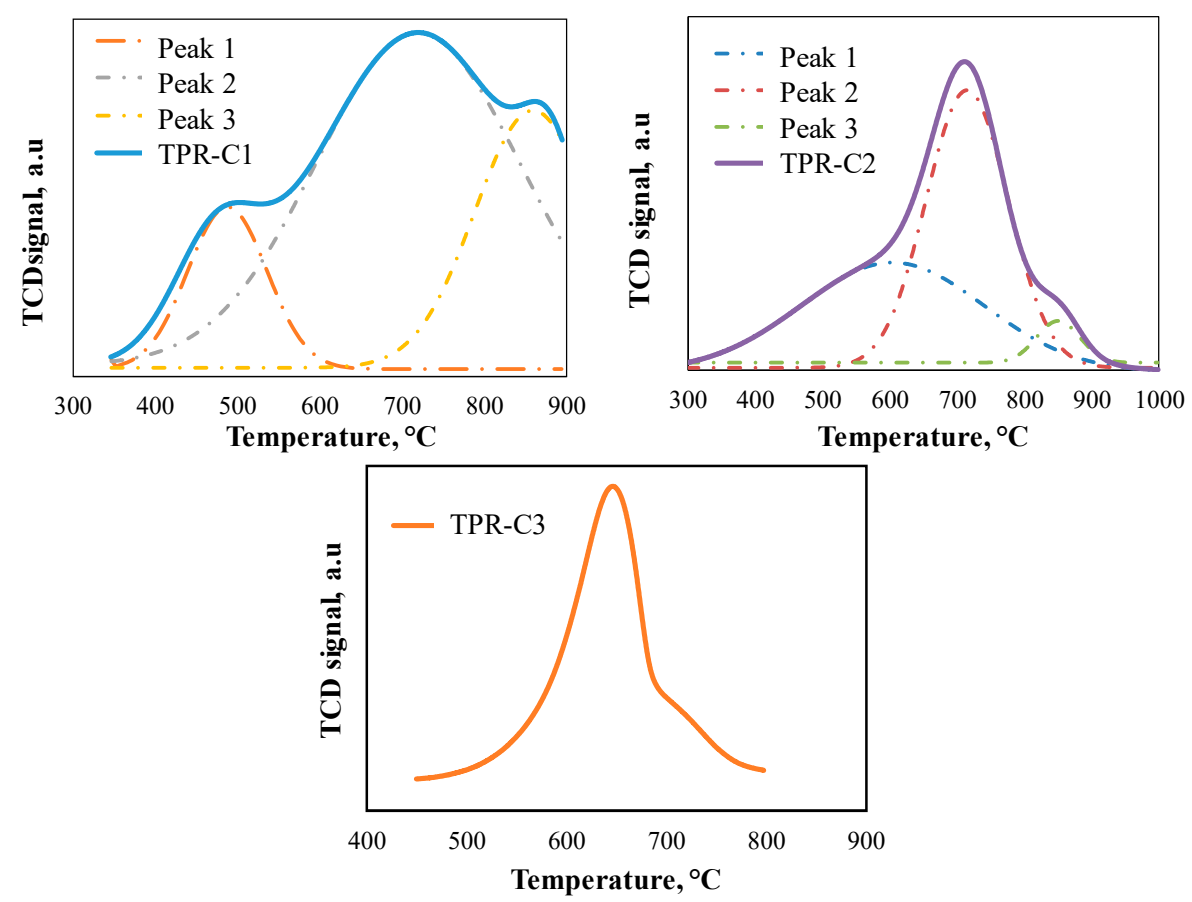

Figure 2. Temperature-programmed reduction (TPR) profile for $\mathrm{C} 1, \mathrm{C} 2$ and $\mathrm{C} 3$ calcined at $500{ }^{\circ} \mathrm{C}$.

Similar behavior has been shown for other Fe based catalysts, for $\mathrm{Fe} / \mathrm{Al}_{2} \mathrm{O}_{3}$ catalyst. Other authors have shown the same three areas that were evidenced in this work. The first one between $250-460{ }^{\circ} \mathrm{C}$ that can be described as a transformation towards $\mathrm{Fe}_{2} \mathrm{O}_{3}$, a second region that is between $480-800{ }^{\circ} \mathrm{C}$ that the authors associate with $\mathrm{Fe}_{3} \mathrm{O}_{4}$ formation. Moreover, the last area that is between $830-950{ }^{\circ} \mathrm{C}$, which is related to the Fe formation [42,43].

Likewise, in this work, the second region again is dominant, but concluded that the area could be ascribable at Fe or $\mathrm{Zn}$ sulfides. The first region only is present when the Fe sulfides are doped with $\mathrm{Zn}$ and the third region increases at the same time, more content of zinc was loaded. Concerning catalyst C3, a particular behavior was found, since the presence of $\mathrm{Zn}$ significantly displaced the temperature towards a higher temperature for $\mathrm{C} 1$ and $\mathrm{C} 2$, this behavior is similar to other studies [44]. Therefore, the reduction peak of $\mathrm{ZnO}$ to a metallic state is around $700^{\circ} \mathrm{C}$, but interactions with sulfur compounds can change the reduction temperature at about $650^{\circ} \mathrm{C}$ [45]. With this analysis is inferred that the C1-C2 mainly had iron phases while C3 has Fe-Zn.

Figure 3 shows a study of the time influence on the reducibility of the catalyst. The catalysts were analyzed at three different times, 15,30 and $45 \mathrm{~min}$. The reduction was made at $750{ }^{\circ} \mathrm{C}$ for $\mathrm{C} 1$, at $850^{\circ} \mathrm{C}$ for $\mathrm{C} 2$ and $800^{\circ} \mathrm{C}$ for $\mathrm{C} 3$ to compare the reducibility at different temperatures. In this test, the same behavior of the previous analysis is evidenced, in which the three catalysts present the same peaks (Figure 2). On the three catalysts was observed the complete reduction of the metallic phase at $15 \mathrm{~min}$, longer reduction times did not show significantly higher reducibility. These results are important to be able to extrapolate at some point, the process at an industrial scale. 

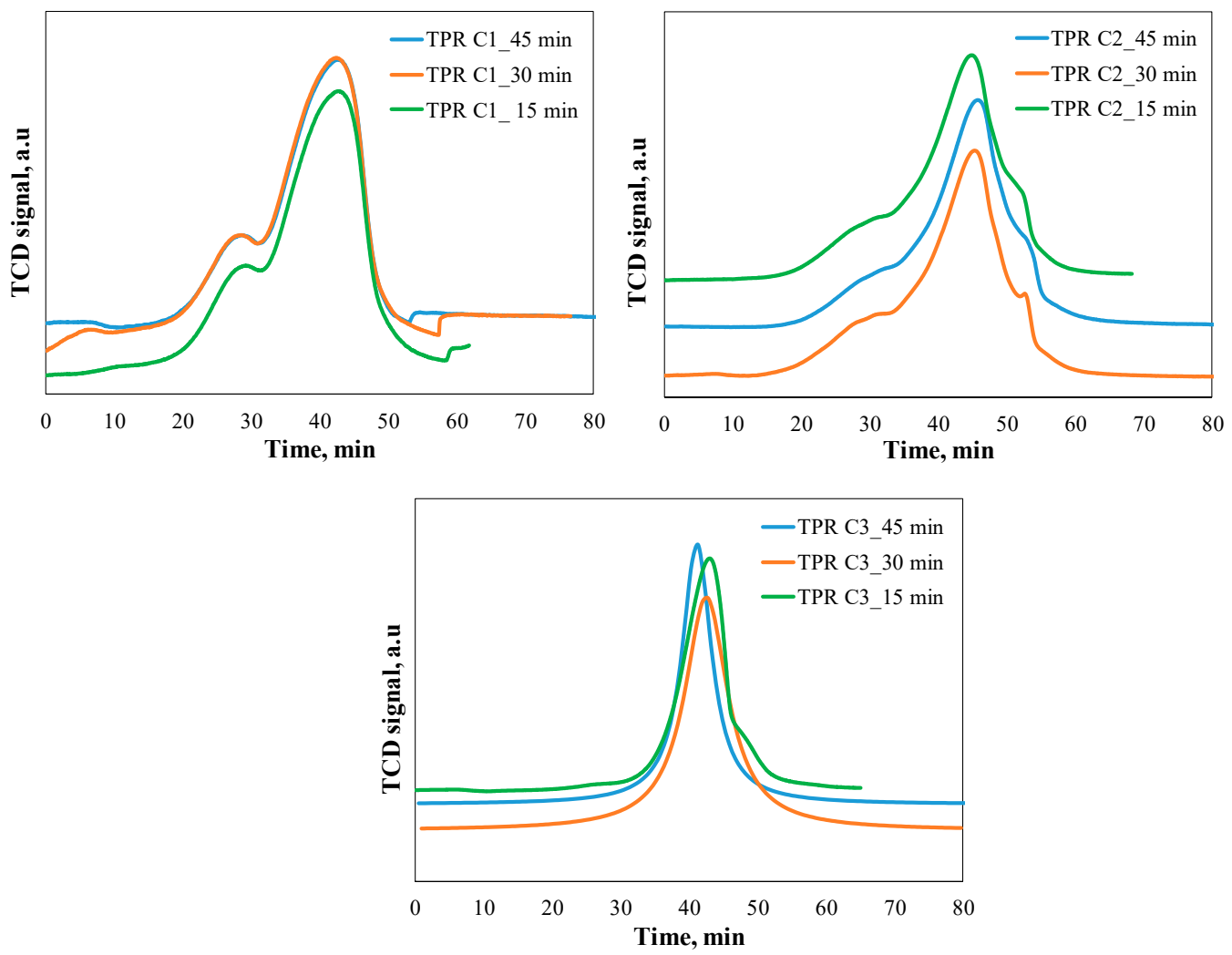

Figure 3. TPR profiles for $\mathrm{C} 1, \mathrm{C} 2$ and $\mathrm{C} 3$ at different reduction times on stream.

\subsection{Metallic and Textural Properties of the Catalytic Material}

The calcined catalyst and the raw sludge were not analyzed through X-ray diffraction (XRD). A similar metallic composition was found in the TPR analysis and while for catalysis application, the synthesized material was reduced. In the case of the reduced catalyst, an XRD analysis was performed. Peak identification was completed with the platform AtomWork: Inorganic Materials Database from NIMS Materials Database (National Institute for Materials Science, Tsukuba, Ibaraki, Japan) [46].

XRD patterns are shown in Figure 4, C1 and C2 had similar patterns, but in the C3, more quantity of peaks had appeared. In the three catalysts were observed mainly peaks corresponding to iron structures and other structures as Zn were defined by FTIR [47-53].

Sulfide structures as $\mathrm{FeS}\left(2 \theta=26.8,28.5,32.85^{\circ}\right)$ were identified in three catalysts, but in C3, $\mathrm{ZnS}\left(2 \theta=30.5^{\circ}\right)$ were identified too. This compound agreed with the sulfur content quantified in the elemental analysis; for this reason, the peaks in $\mathrm{C} 3$ were better defined.

$\mathrm{ZnO}$ structures were present in all the catalysts $\left(2 \theta=31.7,34.28^{\circ}\right)$, but $\mathrm{C} 3$ had more presence of this structure peaks than the other catalysts $\left(2 \theta=47.49,56.52,62.8,67.9\right.$ and $\left.72.7^{\circ}\right), \mathrm{ZnO}_{2}\left(2 \theta=41.23^{\circ}\right)$ on $\mathrm{C} 2$ and $\mathrm{C} 3$, but $\mathrm{Zn} 0$ peak $\left(2 \theta=36.23^{\circ}\right)$ were seen only in $\mathrm{C} 3$. The principal presence in the $\mathrm{Zn}$ structures in C3 could be associated with the TPR analysis, in which a single main peak was evident, due to the presence of these structures. In the case of the other two catalysts, the behavior was different because it presented three reduction regions.

Different iron structures were identified in the three catalysts analyzed. $\mathrm{Fe}_{3} \mathrm{O}_{4}\left(2 \theta=35.5^{\circ}\right)$ were found in $\mathrm{C} 1, \mathrm{Fe}_{2} \mathrm{O}_{3}\left(2 \theta=39.67^{\circ}\right)$ were identified in $\mathrm{C} 2$ and $\mathrm{FeO}\left(2 \theta=50.50,51.5^{\circ}\right)$, while for $\mathrm{C} 3$ the three iron compounds $\mathrm{Fe}_{3} \mathrm{O}_{4}\left(2 \theta=35.5^{\circ}\right), \mathrm{Fe}_{2} \mathrm{O}_{3}\left(2 \theta=39.67^{\circ}\right)$ and $\mathrm{FeO}\left(2 \theta=50.50,51.5^{\circ}\right)$ were evidenced. The main peak of $\mathrm{FeO}\left(2 \theta=44.6,65.1^{\circ}\right)$ was prominent in $\mathrm{C} 1$ and $\mathrm{C} 2$, while in the case of $\mathrm{C} 3$ was decomposed in two lower peaks. Of the three catalysts, $\mathrm{C} 2$ had a lower intensity compared to the other two catalysts. 


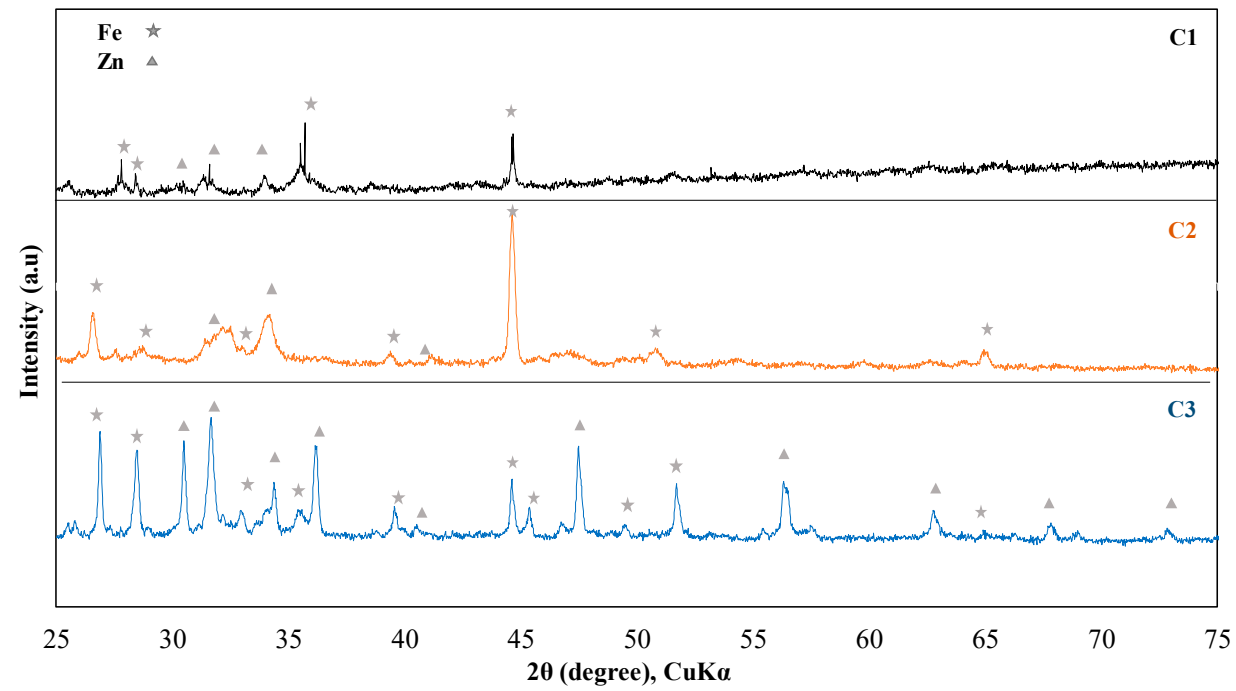

Figure 4. XRD patterns of reduced catalysts C1, C2 and C3.

Scanning electron microscopy-energy dispersive spectrometry (SEM-EDS) confirmed the presence of these metallic phases on the catalytic material. On the surface of $\mathrm{C} 1$ were quantified $41.65 \% \mathrm{Fe}$ and $16.91 \% \mathrm{Zn}, \mathrm{C} 2$ has $19.56 \% \mathrm{Fe}$ and $7.33 \% \mathrm{Zn}$, while $\mathrm{C} 3$ has $7.22 \% \mathrm{Fe}$ and $33.26 \% \mathrm{Zn}$. The results were concordant with XRD element identification. The surface morphology of the catalysts by SEM microscopy is shown in Figure 5.

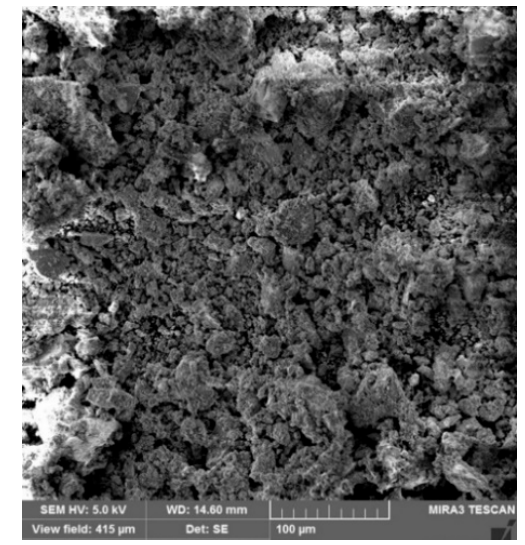

(a)

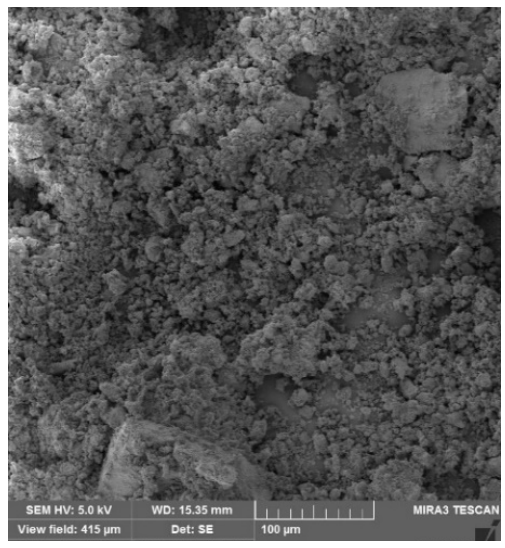

(b)

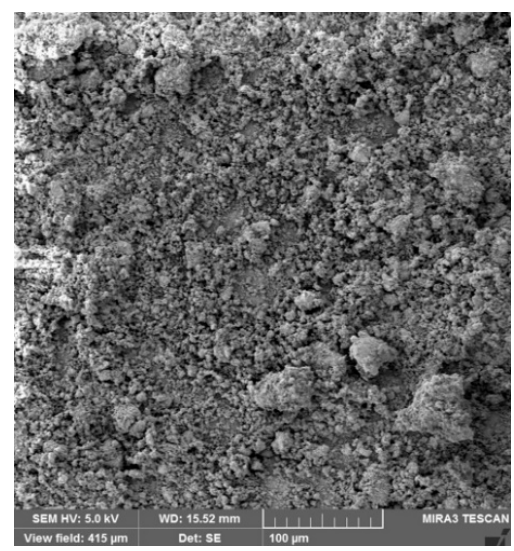

(c)

Figure 5. SEM images of $\mathrm{C} 1(\mathbf{a}), \mathrm{C} 2(\mathbf{b})$ and $\mathrm{C} 3(\mathbf{c})$ calcined at $550{ }^{\circ} \mathrm{C}$ (view at $500 \times$ ). 
No homogeneous particles can be observed in C1-C2, while for C3, it can see some regularity size. Similarly, no crystal-defined structures of catalytic material were found in any of the catalysts evaluated. It may be due to the low homogeneity of the raw sludge. Likewise, differences in morphology between $\mathrm{C} 1$ and $\mathrm{C} 3$ can be seen, which may be related to the differences in the evaluated surface areas, 96.15 and $17.68 \mathrm{~m}^{2} \cdot \mathrm{g}^{-1}$, respectively (Table 1). To obtain irregular particles with good crystallinity is needed high reaction temperature of $1050{ }^{\circ} \mathrm{C}$ [54], but this temperature can cause sinterization for catalyst purposes.

\subsection{Catalytic Evaluation of the Synthesized Materials}

The chemisorption capacity of the catalytic material was analyzed with CO pulses (Figure 6). This information is important to identify catalytic applications correlated at the CO conversion. For catalysts $\mathrm{C} 1$ and $\mathrm{C} 2$, it was observed that both could adsorb CO. It is evident that in both the saturation of the surface is in the third pulse, around $10 \mathrm{~min}$. In addition, the adsorption rate is similar for $\mathrm{C} 1$ and $\mathrm{C} 2$. Therefore, these could be used in $\mathrm{CO}$ reactions.

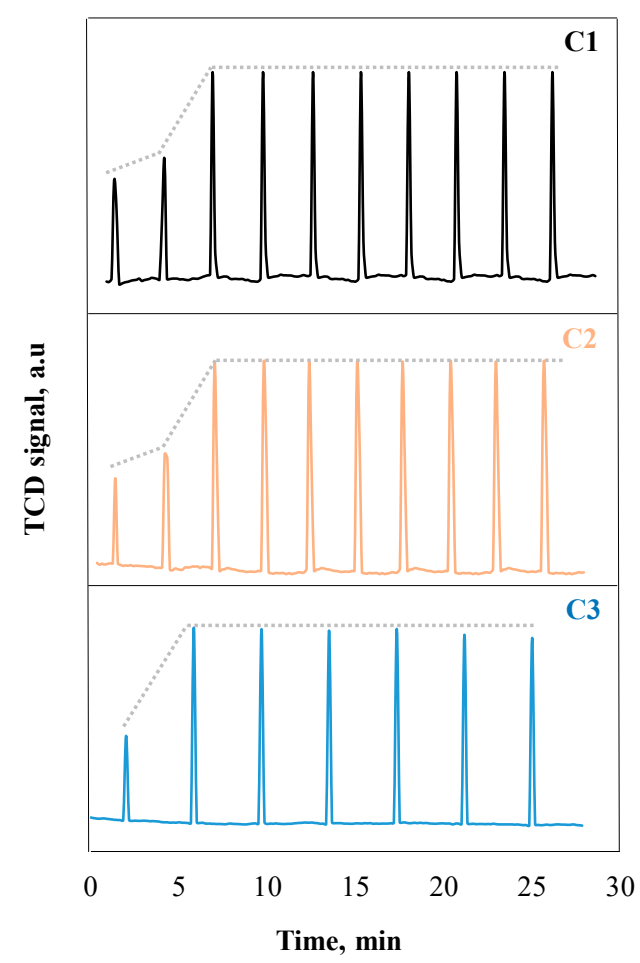

Figure 6. Thermal conductivity detector (TCD) response to CO pulse chemisorption by $\mathrm{C} 1, \mathrm{C} 2$ and C3. $\mathrm{C} 1$ and $\mathrm{C} 2$ saturation reached after 2 peaks $(10 \mathrm{~min}), \mathrm{C} 3$ saturation reached after 1 peak ( $3 \mathrm{~min})$.

A different behavior was found for C3. The first time it was not possible to detect any signal. The CO flux was increased, observing a rapid saturation on the second peak around $3 \mathrm{~min}$, a shorter time than in the other two catalysts. This behavior could be attributed to the $\mathrm{Zn}$ content compared to the other two that the main compound is iron. In addition, another factor is its low specific surface.

Therefore, this catalyst, C3, does not have characteristics to be used as a catalyst in CO processes.

The catalytic activity of the synthesized materials was analyzed in a reaction to the thermal decomposition of heavy crude oil. The reaction was carried out by thermogravimetric analysis (TGA) in an $\mathrm{N}_{2}$ atmosphere. This technique has been used previously to characterize the heavy crude oils [55-57].

The loss of mass is considered as indicative of catalytic decomposition, where higher mass-loss on crude oil was regarded as better catalytic activity. These assays were compared with reactions without catalyst and a reaction performed with a commercial catalyst (FCC type, $265 \mathrm{~m}^{2} \cdot \mathrm{g}^{-1}$ ) at the 
same space-time ( $0.15 \mathrm{~g}$ catalyst $\mathrm{g}^{-1}$ crude oil). The results are in Table 2; all the catalysts promote the weight-loss while the temperature increases as expected.

Table 2. Effect of the catalyst on the weight loss of crude oil on the thermal decomposition reaction.

\begin{tabular}{|c|c|c|c|c|c|}
\hline $\begin{array}{c}\text { Temperature } \\
\text { of Reaction, }{ }^{\circ} \mathrm{C}\end{array}$ & Sample & $\begin{array}{l}\text { Weight } \\
\text { Loss, \% }\end{array}$ & Kinetic Expression & $\mathbf{R}^{2}$ & $\begin{array}{c}\text { Rate of Mass } \\
\text { Loss (avg.), } \\
\text { mg.min }{ }^{-1}\end{array}$ \\
\hline \multirow{3}{*}{400} & Crude oil without catalyst & 54.30 & $\frac{\mathrm{dm}}{\mathrm{dt}}=0.0015 \mathrm{~m}_{\mathrm{A}}^{0.5}$ & 0.90 & 0.57 \\
\hline & Crude oil + C1 & 59.28 & $\frac{\mathrm{dm}}{\mathrm{dt}}=0.0017 \mathrm{~m}_{\mathrm{A}}^{0.5}$ & 0.92 & 0.61 \\
\hline & Crude oil + commercial cat. & 56.00 & $\frac{\mathrm{dm}}{\mathrm{dt}}=0.0020 \mathrm{~m}_{\mathrm{A}}^{0.5}$ & 0.95 & 0.65 \\
\hline \multirow{4}{*}{450} & Crude oil without catalyst & 73.20 & $\frac{\mathrm{dm}}{\mathrm{dt}}=0.0016 \mathrm{~m}_{\mathrm{A}}^{0.5}$ & 0.91 & 0.64 \\
\hline & Crude oil + C2 & 84.50 & $\frac{\mathrm{dm}}{\mathrm{dt}}=0.0018 \mathrm{~m}_{\mathrm{A}}^{0.5}$ & 0.90 & 0.71 \\
\hline & Crude oil + C3 & 82.10 & $\frac{\mathrm{dm}}{\mathrm{dt}}=0.0019 \mathrm{~m}_{\mathrm{A}}^{0.5}$ & 0.92 & 0.69 \\
\hline & Crude oil + commercial cat. & 77.95 & $\frac{\mathrm{dm}}{\mathrm{dt}}=0.0019 \mathrm{~m}_{\mathrm{A}}^{0.5}$ & 0.94 & 0.81 \\
\hline
\end{tabular}

The three catalysts promote around 5\% more mass-loss than the experiment without catalyst and some higher mass-loss compared with a commercial catalyst (C2-C3). For C2 and C3, the mass-loss was enhanced at temperatures higher than $400{ }^{\circ} \mathrm{C}$. The catalytic effect was analyzed by mass-loss data, and it was used to define a kinetic model. The kinetic analysis was done applying the integral method of linearization of kinetic expression $2 \mathrm{~m}^{0.5} \mathrm{vs}$. time. The kinetic order of 0.5 provided the best fit with the experimental data according to the determination coefficient $\left(R^{2}\right)$.

The average rate of mass loss was calculated for the reactions. The experimental data were replaced in the kinetic expression for each time. The numerical value at $\left(\frac{d m}{d t}\right)$ was obtained for the extension of reaction.

Kinetic expressions showed that the rate of thermal decomposition promoted by catalytic material derived from sludge had similar values than the commercial catalyst, and an evident higher rate than the test without a catalyst, mainly in $\mathrm{C} 2$ and $\mathrm{C} 3$ to the reaction at $450{ }^{\circ} \mathrm{C}$. For a technical limitation due to the highly exothermic reaction presented by crude oil itself, it was not able to perform thermal decomposition experiments above $450{ }^{\circ} \mathrm{C}$.

These results permit concluded that the catalyst can be used in cracking applications to replace commercial catalysts.

\section{Materials and Methods}

The samples of sludges were taken from three galvanic companies with similar technologies located in Quito, Ecuador (Table 3). For company 1 the sludge was named L1; for company 2, L2 and company 3, L3. The catalytic materials derived from the sludges were identified as C1, C2 and C3.

Table 3. Nomenclature used for the different sludges evaluated.

\begin{tabular}{ccc}
\hline Company & Sludge & Catalytic Material \\
\hline Company 1 & L1 & C1 \\
\hline Company 2 & L2 & C2 \\
\hline Company 3 & L3 & C3 \\
\hline
\end{tabular}

All the analyses of characterization were performed in triplicate to guarantee the best possible results. 


\subsection{Catalytic Preparation}

The residual sludges were dried as is described on ASTM-D2216 in a drying oven (Nabertherm-TR60, Bahnhofstr, Lilienthal, Germany) for $4 \mathrm{~h}$. The dried sludges were sieved between 150-180 $\mu \mathrm{m}$ with a Tyler's-sieve series.

The residual sludges were calcined between $400-700{ }^{\circ} \mathrm{C}$ for $4 \mathrm{~h}$ in a muffle furnace (Thermo Scientific- Thermolyne, Waltham, MA, USA). This process was done to remove the organic residues and to oxidize the metallic phase on the sludges. After the thermal process, the residual sludges were considered as catalytic material.

The sludges and the catalytic material were analyzed by elemental analysis based on the ASTM-D5373 to identify the organic material in an elemental analyzer (Elementar-Vario Macro Cube, Langenselbold, Germany). Around $10 \mathrm{mg}$ of the sample was exposed to oxidative decomposition at $1150{ }^{\circ} \mathrm{C}$ and subsequent reduction at $850{ }^{\circ} \mathrm{C}$, to quantify carbon, hydrogen, nitrogen and sulfur (CHNS) composition. Before the experiment, the samples were prepared by digestion microwave system (Milestone-ETHOS UP, Sorisole, BG, Italy).

Fourier-transformed infrared spectroscopy (FTIR) (PerkinElmer-Spectrum Two spectrometer, Waltham, MA, USA) was used to identify the bonds related to organic and inorganic compounds on the sludges. The dried samples were pulverized in an agate mortar and then mixed with $\mathrm{KBr}$ (PerkinElmer, Waltham, MA, USA), in a weight ratio 1:100. Later, a pellet was formed in a press and then read on FTIR.

\subsection{Catalyst Characterization}

The surface area and pore volume of the catalytic material were determined by $\mathrm{N}_{2}$ adsorption-desorption in a surface area analyzer (Horiba-SA 9600, minami-ku, Kyoto, Japan). The equipment uses the flowing gas method to acquire gas adsorption and desorption curves, and the surface area was by the single-point BET method. A sample of $0.15 \mathrm{~g}$ was loaded in a $U$-tube and degasified for $2 \mathrm{~h}$ at $300{ }^{\circ} \mathrm{C}$ to clean the surface. Later, the $\mathrm{N}_{2}$ adsorption-desorption was done using liquid $\mathrm{N}_{2}$ (Enox S.A, Quito, Pichincha, Ecuador).

Temperature-programmed reduction (TPR) was done to study the reducibility of the catalysts in an automated chemisorption analyzer (Micromeritics-AutoChem II, 2920, Norcross, GA, USA). The catalyst samples $(200 \mathrm{mg})$ were reduced at the heating rate of $10{ }^{\circ} \mathrm{C} \cdot \mathrm{min}^{-1}$ up $1000^{\circ} \mathrm{C}$ under a flow (50 $\mathrm{mL} \cdot \mathrm{min}^{-1}$ ) of $10 \% \mathrm{H}_{2} / \mathrm{Ar}$ (99.999\%, INDURA, Quito, Pichincha, Ecuador). The consumption of hydrogen was monitored with a thermal conductivity detector (TCD). Experiments were performed at 15, 30 and $45 \mathrm{~min}$ to define the effect to the time on the total reduction.

X-ray diffraction was done (Malvern Panalytical-Empyrean, Malvern Worcestershire, UK) with $\mathrm{CuK} \alpha$ radiation source and Scanning electron microscopy SEM/EDS in a (TESCAN-MIRA3 FEG SEM, Brno, Kohoutovice, Czech Republic) were used to study the metallic content on the reduced catalyst. These assays were done in an external laboratory CENCINAT ESPE Laboratory (Sangolquí, Pichincha, Ecuador).

\subsection{Catalytic Material Evaluation}

The CO chemisorption was studied with CO pulses technique (Micromeritics-AutoChem II, 2920, Norcross, GA, USA). Before the experiments, the catalysts were reduced, as described previously. Chemisorption experiments were done with $200 \mathrm{mg}$ of the samples at $50{ }^{\circ} \mathrm{C}$ [58] exposed at the catalyst at 10\% CO/He (99,999\%, INDURA, Quito, Pichincha, Ecuador). The total adsorption amount of CO was detected by TCD. The gas uptake was measured from a sequence of small pulses until saturation was obtained.

The catalytic activity of the synthesized materials was evaluated with a thermal decomposition reaction with a crude oil sample (18.9 ${ }^{\circ} \mathrm{API}$, PETROECUADOR, Esmeraldas, Esmeraldas, Ecuador). A thermogravimetric analysis in a thermo-balance (Mettler Toledo-TGA1 SF/1100, Columbus, OH, USA), 
was realized in a reaction atmosphere of $\mathrm{N}_{2}\left(30 \mathrm{~mL} \cdot \mathrm{min}^{-1}, 99,999 \%\right.$, INDURA, Quito, Pichincha, Ecuador) to determine the loss of mass promoted for the catalytic activity. In this assay, a space-time of $0.15 \mathrm{~g}$ catalyst $\mathrm{g}^{-1}$ crude oil was used. The studies were performed at $400{ }^{\circ} \mathrm{C}$ for $\mathrm{C} 1$ and $450{ }^{\circ} \mathrm{C}$ for $\mathrm{C} 2-\mathrm{C} 3$ with a rate of heating to $10^{\circ} \mathrm{C} \cdot \mathrm{min}^{-1}$. The reaction had $1 \mathrm{~h}$ to time on stream and the mass loss was recorded every $35 \mathrm{~s}$.

Before the study, the catalytic material was reduced in a 10\% H2/Ar. Assays without catalyst and FCC commercial catalyst (GRACE-ResidCrackeR, Columbia, MD, USA) were done to compare the catalytic effect on the crude oil. The reaction rate of thermo-catalytic decomposition was determined through the integral method of data analysis considering the loss of mass vs. time of reaction.

\section{Conclusions}

Due to the metal content-mainly iron in their composition—sludge from wastewater treatment from galvanic industries can be used as catalytic material in the thermal decomposition of hydrocarbons-after a thermal treatment.

The best catalytic activity was evidenced at the sludges calcinated at $400{ }^{\circ} \mathrm{C}$ for $\mathrm{C} 1$ and $500{ }^{\circ} \mathrm{C}$ for C2-C3. The catalysts had specific surface areas of $96.15,63.36$ and $17.68 \mathrm{~m}^{2} \cdot \mathrm{g}^{-1}$, respectively. For the reduction of the catalyst, the best condition of time was $15 \mathrm{~min}$ and 750,850 and $800{ }^{\circ} \mathrm{C}$ for $\mathrm{C} 1, \mathrm{C} 2$ and $\mathrm{C} 3$, respectively. The prepared catalyst evidenced at $\mathrm{CO}$ chemisorption capacity, those with the best performance were catalysts $\mathrm{C} 1$ and $\mathrm{C} 2$.

The catalytic material enhanced the rate of reaction on the thermal decomposition of crude oil promotes more weight-loss in a thermo-gravimetric analysis compared to the reactions without the catalyst.

The synthesis presented here is a good and sustainable alternative to commercial (heavy oil cracking) catalysts due to the easiness of synthesis procedures required, the low E-factor obtained and the recycling of industrial waste promoted.

Author Contributions: Conceptualization, C.M., H.S. and A.D.L.R.; methodology, C.M., H.S. and A.D.L.R.; validation, C.M., H.S. and A.D.L.R.; formal analysis, E.V.-B., J.C., P.L.-L. and C.M.; investigation, E.V.-B., J.C., P.L.-L. and C.M.; resources, C.M. and A.D.L.R.; data curation E.V.-B., J.C. and P.L.L.; writing-original draft preparation, C.M., E.V.-B., A.D.L.R., P.L.-L. and J.F.S.; writing—review and editing, C.M., H.S. and J.F.S.; visualization, C.M., H.S. and A.D.L.R.; supervision, C.M.; project administration, C.M.; funding acquisition, C.M. and A.D.L.R. All authors have read and agreed to the published version of the manuscript.

Funding: This work was carried with the financial support of the Central University of Ecuador (UCE) Advanced Projects Program 2017, Project No 23.

Acknowledgments: The authors are grateful to the Chemical Engineering Faculty (UCE) for the lab facilities and J. Alvear from Laboratory of Catalyst (FIQ-UCE) for her technical assistance. Juan F. Saldarriaga thanks to Dept. Civil and Environmental Engineering of the Universidad de los Andes.

Conflicts of Interest: The authors declare no conflict of interest.

\section{References}

1. Kaza, S.; Yao, L.C.; Bhada-Tata, P.; Van Woerden, F. What a Waste 2.0: A Global Snapshot of Solid Waste Management to 2050; Urban Development; World Bank: Washington, DC, USA, 2018.

2. Mymrin, V.; Borgo, S.C.; Alekseev, K.; Avanci, M.A.; Rolim, P.H.B.; Argenda, M.A.; Klitzke, W.; Gonçalves, A.J.; Catai, R.E. Galvanic Cr-Zn and spent foundry sand waste application as valuable components of sustainable ceramics to prevent environment pollution. Int. J. Adv. Manuf. Technol. 2020, 107, 1239-1250. [CrossRef]

3. Pérez-Villarejo, L.; Martínez-Martínez, S.; Carrasco-Hurtado, B.; Eliche-Quesada, D.; Ureña-Nieto, C.; Sánchez-Soto, P.J. Valorization and inertization of galvanic sludge waste in clay bricks. Appl. Clay Sci. 2015, 105-106, 89-99. [CrossRef]

4. Huang, M.; Chen, L.; Chen, D.; Zhou, S. Characteristics and aluminum reuse of textile sludge incineration residues after acidification. J. Environ. Sci. 2011, 23, 1999-2004. [CrossRef]

5. Sohaimi, K.S.A.; Ngadi, N.; Mat, H.; Inuwa, I.M.; Wong, S. Synthesis, characterization and application of textile sludge biochars for oil removal. J. Environ. Chem. Eng. 2017, 5, 1415-1422. [CrossRef] 
6. Cagno, E.; Trucco, P. Cleaner technology transfer in the Italian galvanic industry: Economic and know-how issues. J. Clean. Prod. 2008, 16, S32-S36. [CrossRef]

7. Stepanov, S.; Morozov, N.; Morozova, N.; Ayupov, D.; Makarov, D.; Baishev, D. Efficiency of Use of Galvanic Sludge in Cement Systems. Procedia Eng. 2016, 165, 1112-1117. [CrossRef]

8. Svoboda, K.; Baxter, D.; Martinec, J. Nitrous oxide emissions from waste incineration. Chem. Pap. 2006, 60, 78-90. [CrossRef]

9. Werle, S. A reburning process using sewage sludge-derived syngas. Chem. Pap. 2012, 66, 99-107. [CrossRef]

10. Rossini, G.; Bernardes, A.M. Galvanic sludge metals recovery by pyrometallurgical and hydrometallurgical treatment. J. Hazard. Mater. 2006, 131, 210-216. [CrossRef]

11. Cichowicz, R.; Stelegowski, A. Effect of thermal sludge processing on selected components of air quality in the vicinity of a wastewater treatment plant. Chem. Pap. 2019, 73, 843-849. [CrossRef]

12. Castañeda Bocanegra, J.J.; Espejo Mora, E.; Cubillos González, G.I. Encapsulation in ceramic material of the metals $\mathrm{Cr}, \mathrm{Ni}$, and $\mathrm{Cu}$ contained in galvanic sludge via the solidification/stabilization method. J. Environ. Chem. Eng. 2017, 5, 3834-3843. [CrossRef]

13. Felisberto, R.; Santos, M.C.; Arcaro, S.; Basegio, T.M.; Bergmann, C.P. Assessment of environmental compatibility of glass-ceramic materials obtained from galvanic sludge and soda-lime glass residue. Process Saf. Environ. Prot. 2018, 120, 72-78. [CrossRef]

14. Luz, C.A.; Rocha, J.C.; Cheriaf, M.; Pera, J. Valorization of galvanic sludge in sulfoaluminate cement. Constr. Build. Mater. 2009, 23, 595-601. [CrossRef]

15. Bednarik, V.; Vondruska, M.; Koutny, M. Stabilization/solidification of galvanic sludges by asphalt emulsions. J. Hazard. Mater. 2005, 122, 139-145. [CrossRef] [PubMed]

16. Wong, S.; Yac'cob, N.A.N.; Ngadi, N.; Hassan, O.; Inuwa, I.M. From pollutant to solution of wastewater pollution: Synthesis of activated carbon from textile sludge for dye adsorption. Chin. J. Chem. Eng. 2018, 26, 870-878. [CrossRef]

17. Amaral, F.A.D.; dos Santos, V.S.; Bernardes, A.M. Metals recovery from galvanic sludge by sulfate roasting and thiosulfate leaching. Miner. Eng. 2014, 60, 1-7. [CrossRef]

18. Huyen, P.T.; Dang, T.D.; Tung, M.T.; Huyen, N.T.T.; Green, T.A.; Roy, S. Electrochemical copper recovery from galvanic sludge. Hydrometallurgy 2016, 164, 295-303. [CrossRef]

19. Jandová, J.; Štefanová, T.; Niemczyková, R. Recovery of Cu-concentrates from waste galvanic copper sludges. Hydrometallurgy 2000, 57, 77-84. [CrossRef]

20. Silva, J.E.; Paiva, A.P.; Soares, D.; Labrincha, A.; Castro, F. Solvent extraction applied to the recovery of heavy metals from galvanic sludge. J. Hazard. Mater. 2005, 120, 113-118. [CrossRef]

21. Klose, F.; Scholz, P.; Kreisel, G.; Ondruschka, B.; Kneise, R.; Knopf, U. Catalysts from waste materials. Appl. Catal. B Environ. 2000, 28, 209-221. [CrossRef]

22. Sushil, S.; Scholz, P.; Pollok, K.; Ondruschka, B.; Batra, V.S. Application of industrial waste based catalysts for total oxidation of propane. Chem. Eng. J. 2011, 166, 568-578. [CrossRef]

23. Lou, J.-C.; Chang, C.-K. Catalytic Oxidation of CO Over a Catalyst Produced in the Ferrite Process. Environ. Eng. Sci. 2006, 23, 1024-1032. [CrossRef]

24. Zhang, J.; Zhang, J.; Xu, Y.; Su, H.; Li, X.; Zhou, J.Z.; Qian, G.; Li, L.; Xu, Z.P. Efficient Selective Catalytic Reduction of NO by Novel Carbon-doped Metal Catalysts Made from Electroplating Sludge. Environ. Sci. Technol. 2014, 48, 11497-11503. [CrossRef] [PubMed]

25. Montero, C.; Castañeda, K.M.; Suntasig, Y.M.O.; Oña, D.R.F.; De La Rosa, A. Catalyst Based on Sludge Derived from Wastewater Treatment of Textile Industry. Chem. Eng. Trans. 2018, 70, 931-936. [CrossRef]

26. Lin, B.; Huang, Q.; Yang, Y.; Chi, Y. Preparation of Fe-char catalyst from tank cleaning oily sludge for the catalytic cracking of oily sludge. J. Anal. Appl. Pyrolysis 2019, 139, 308-318. [CrossRef]

27. Lee, M.S.; Park, K.Y.; Park, H.K.; Kang, T.W.; Jang, H.D.; Han, S.S.; Jeon, J.-K. Prospective application of carbon-silica derived from SiC-Si sludge as a support for Fe catalysts. Korean J. Chem. Eng. 2017, 34, 100-104. [CrossRef]

28. Nam, S.-B.; Park, Y.-S.; Yun, Y.-S.; Gu, J.-H.; Sung, H.-J.; Horio, M. Catalytic application of metallic iron from the dyeing sludge ash for benzene steam reforming reaction in tar emitted from biomass gasification. Korean J. Chem. Eng. 2016, 33, 465-472. [CrossRef]

29. Zhu, F.; Jiang, H.; Zhang, Z.; Zhao, L.; Wang, J.; Hu, J.; Zhang, H. Research on Drying Effect of Different Additives on Sewage Sludge. Procedia Environ. Sci. 2012, 16, 357-362. [CrossRef] 
30. Ronda, A.; Gómez-Barea, A.; Haro, P.; de Almeida, V.F.; Salinero, J. Elements partitioning during thermal conversion of sewage sludge. Fuel Process. Technol. 2019, 186, 156-166. [CrossRef]

31. Guangyin, Z.; Youcai, Z. Chapter Three-Sewage Sludge Solidification/Stabilization and Drying/Incineration Process. In Pollution Control and Resource Recovery for Sewage Sludge; Guangyin, Z., Youcai, Z., Eds.; Butterworth-Heinemann: Oxford, UK, 2017; pp. 101-160, ISBN 978-0-12-811639-5.

32. Kuzin, E.N.; Chernyshev, P.I.; Vizen, N.S.; Krutchinina, N.E. The Purification of the Galvanic Industry Wastewater of Chromium(VI) Compounds Using Titanium(III) Chloride. Russ. J. Gen. Chem. 2018, 88, 2954-2957. [CrossRef]

33. Kliopova, I.; Staniškis, J. Optimization of Galvanic Wastewater Treatment Processes. In Modern Tools and Methods of Water Treatment for Improving Living Standards; Omelchenko, A., Pivovarov, A.A., Swindall, W.J., Eds.; Springer: Dordrecht, the Netherlands, 2005; pp. 197-208.

34. Torres-Luna, J.A.; Carriazo, J.G.; Sanabria-González, N.R. Calcination Temperature Effect on structural and textural properties of Fe(iii)-TiO 2 . Rev. Fac. Cienc. Básicas 2014, 10, 186-195. [CrossRef]

35. Sheldon, R.A. Fundamentals of green chemistry: Efficiency in reaction design. Chem. Soc. Rev. 2012, 41, 1437-1451. [CrossRef] [PubMed]

36. Dicks, A.P.; Hent, A. The E Factor and Process Mass Intensity. In Green Chemistry Metrics: A Guide to Determining and Evaluating Process Greenness; SpringerBriefs in Molecular Science; Dicks, A.P., Hent, A., Eds.; Springer International Publishing: Cham, Switzerland, 2015; pp. 45-67, ISBN 978-3-319-10500-0.

37. Tieves, F.; Tonin, F.; Fernández-Fueyo, E.; Robbins, J.M.; Bommarius, B.; Bommarius, A.S.; Alcalde, M.; Hollmann, F. Energising the E-factor: The E+-factor. Tetrahedron 2019, 75, 1311-1314. [CrossRef]

38. Sahoo, S.K.; Agarwal, K.; Singh, A.K.; Polke, B.G.; Raha, K.C. Characterization of $\gamma$ - and $\alpha-\mathrm{Fe}_{2} \mathrm{O}_{3}$ nano powders synthesized by emulsion precipitation-calcination route and rheological behaviour of $\alpha-\mathrm{Fe}_{2} \mathrm{O}_{3}$. Int. J. Eng. Sci. Technol. 2010, 2. [CrossRef]

39. Ortego, J.D.; Barroeta, Y.; Cartledge, F.K.; Akhter, H. Leaching effects on silicate polymerization. An FTIR and silicon-29 NMR study of lead and zinc in portland cement. Environ. Sci. Technol. 1991, 25, 1171-1174. [CrossRef]

40. Paterson, E. The Iron Oxides. Structure, Properties, Reactions, Occurrences and Uses. Clay Min. 2006, 34, 209-210. [CrossRef]

41. Iqbal, A.; Jacob, J.; Mahmood, A.; Mehboob, K.; Mahmood, K.; Ali, A.; Bukhari, T.H.; Adrees, M.; Ibrahim, M.; Ahmad, M. Synthesis and characterization of $\mathrm{Zn}-\mathrm{Mn}-\mathrm{Fe}$ nano oxide composites for the degradation of reactive yellow 15 dye. Phys. B Condens. Matter 2020, 588, 412210. [CrossRef]

42. Fakeeha, A.; Khan, W.; Ibrahim, A.; Al-Otaibi, R.; Alfatesh, A.; Soliman, M.; Abasaeed, A. Alumina supported iron catalyst for hydrogen production: Calcination study. Int. J. Adv. Chem. Eng. Biol. Sci. 2015, 2, 139-141. [CrossRef]

43. Li, H.; Liu, J.; Li, J.; Hu, Y.; Wang, W.; Yuan, D.; Wang, Y.; Yang, T.; Li, L.; Sun, H.; et al. Promotion of the Inactive Iron Sulfide to an Efficient Hydrodesulfurization Catalyst. ACS Catal. 2017, 7, 4805-4816. [CrossRef]

44. Liang, K.; Zhang, C.; Xiang, H.; Yang, Y.; Li, Y. Effects of modified $\mathrm{SiO}_{2}$ on $\mathrm{H}_{2}$ and $\mathrm{CO}$ adsorption and hydrogenation of iron-based catalysts. J. Fuel Chem. Technol. 2019, 47, 769-779. [CrossRef]

45. Song, H.; Cui, H.; Li, F. The effect of $\mathrm{Zn}-\mathrm{Fe}$ modified $\mathrm{S}_{2} \mathrm{O}_{8} 2-/ \mathrm{ZrO}_{2}-\mathrm{Al}_{2} \mathrm{O}_{3}$ catalyst for n-pentane hydroisomerization. Res. Chem. Intermed. 2016, 42, 3029-3038. [CrossRef]

46. National Institute for Materials Science NIMS Materials Database (MatNavi). Available online: https: //mits.nims.go.jp/index_en.html (accessed on 12 May 2020).

47. Glavee, G.N.; Klabunde, K.J.; Sorensen, C.M.; Hadjipanayis, G.C. Chemistry of Borohydride Reduction of Iron(II) and Iron(III) Ions in Aqueous and Nonaqueous Media. Formation of Nanoscale $\mathrm{Fe}, \mathrm{FeB}$, and $\mathrm{Fe}_{2} \mathrm{~B}$ Powders. Inorg. Chem. 1995, 34, 28-35. [CrossRef]

48. Legodi, M.A.; de Waal, D. The preparation of magnetite, goethite, hematite and maghemite of pigment quality from mill scale iron waste. Dyes Pigments 2007, 74, 161-168. [CrossRef]

49. Picasso, G.; Sun Kou, R.; Gómez, G.; Hermoza, E.; López, A.; Pina, M.P.; Herguido, J. Nanosized catalyst based on Fe Oxide for combustion of n-hexane. Rev. Soc. Quím. Perú 2009, 75, 163-176.

50. Caballero, D.; Mass, J.; Landinez, D. Optical and Structural Characterization of $\mathrm{Zn}_{2} \mathrm{TiO}_{4}$ capped with $\mathrm{Mg}$. Tumbaga 2011, 6, 165-172.

51. Kumar, H.; Rani, R. Structural and Optical Characterization of ZnO Nanoparticles Synthesized by Microemulsion Route. Int. Lett. Chem. Phys. Astron. 2013, 14, 26-36. [CrossRef] 
52. Dou, J.; Li, X.; Tahmasebi, A.; Xu, J.; Yu, J. Desulfurization of coke oven gas using char-supported Fe-Zn-Mo catalysts: Mechanisms and thermodynamics. Korean J. Chem. Eng. 2015, 32, 2227-2235. [CrossRef]

53. Yan, Z.; Kang, Y.; Li, D.; Liu, Y.C. Catalytic oxidation of sulfur dioxide over $\alpha-\mathrm{Fe}_{2} \mathrm{O}_{3} / \mathrm{SiO}_{2}$ catalyst promoted with Co and Ce oxides. Korean J. Chem. Eng. 2020, 37, 623-632. [CrossRef]

54. Yin, X.; Yue, M.; Lu, Q.; Liu, M.; Wang, F.; Qiu, Y.; Liu, W.; Zuo, T.; Zha, S.; Li, X.; et al. An Efficient Process for Recycling Nd-Fe-B Sludge as High-Performance Sintered Magnets. Engineering 2020, 6, 165-172. [CrossRef]

55. Kök, M.V.; Varfolomeev, M.A.; Nurgaliev, D.K. Crude oil characterization using TGA-DTA, TGA-FTIR and TGA-MS techniques. J. Pet. Sci. Eng. 2017, 154, 537-542. [CrossRef]

56. Simo, S.M.; Naman, S.A.; Ahmed, K.R.; Faritovich, A.A. Evaluation of Two Kurdistan-Iraq Crude Oil (T-21A, PF2) by Derivatographic Method. Int. Res. J. Pure Appl. Chem. 2020, 38-46. [CrossRef]

57. Park, Y.C.; Paek, J.-Y.; Bae, D.-H.; Shun, D. Study of pyrolysis kinetics of Alberta oil sand by thermogravimetric analysis. Korean J. Chem. Eng. 2009, 26, 1608-1612. [CrossRef]

58. Liu, S.; Ren, J.; Zhu, S.; Zhang, H.; Lv, E.; Xu, J.; Li, Y.-W. Synthesis and characterization of the Fe-substituted ZSM-22 zeolite catalyst with high n-dodecane isomerization performance. J. Catal. 2015, 330, 485-496. [CrossRef]

(C) 2020 by the authors. Licensee MDPI, Basel, Switzerland. This article is an open access article distributed under the terms and conditions of the Creative Commons Attribution (CC BY) license (http://creativecommons.org/licenses/by/4.0/). 